\title{
Emotional Intelligence of School Teachers
}

\author{
Dr.D.Ponmozhi ${ }^{1}$, T.Ezhilbharathy ${ }^{2}$ \\ Principal, O.P.R. Memorial College of Education, Vadalur, Tamilnadu, India. \\ M.Ed., student, O.P.R. Memorial College of Education, Vadalur, Tamilnadu, India
}

\begin{abstract}
The contemporary inquiry has been commenced in order to study the Emotional Intelligence of school teacher of Cuddalore District in Tamilnadu. The random sampling technique was used to collect 150 samples from area of study. Normative survey method was used. This study is envisioned to find out the levels of Emotional intelligence of teachers and if there is any significant difference between the selected pairs of subsamples. Emotional Intelligence scale constructed and validated by Hyde, Dhar, \& Pethe, (2001) was used to collect the data. This study reveals that the majority of teachers Emotionally Intelligence were high. There exists significant difference between sub samples related to gender, age, locality, Qualification, Major subject, Number of children and Spouse salary. A stepwise regression was used to find factors contributing emotional intelligence of teachers. Among the 13 predictors 1 was found in the 1 step. The model was statistically significant and accounted for approximately 15\% of the variance of emotional intelligence. Inspection of the structure coefficient suggests that gender alone is a strong indicator of emotional intelligence.
\end{abstract}

Keywords: Emotional Intelligence, School Teacher, Gender, Age, Locality, Type Of School, Qualification, Major Subject, Class Handled, Designation, Monthly Income, No Of Dependent, No Of Children, Spouse Employment And Spouse Salary.

\section{Introduction}

Emotional intelligence also determined by environment and heredity. Until Daniel Goleman's theory all the psychologists believe that IQ alone determines the success of an individual. Researches and experiments conducted in 90s replacing IQ with the concept of Emotional Quotient (E.Q). A person's emotional intelligence measured through their E.Q may be a greater predictor of success than their I.Q. The term Emotional Intelligence was devised by Peter Salovey and John D. Mayer (1990). But it was disseminated by Daniel Goleman.

\section{Emotional intelligence of teachers}

Emotional intelligence of teachers plays vital role in managing their own life and deal effectively with the feelings of others. Teachers need to develop smooth relationship with students, Teachers, administrators and parents. The holistic approach influences emotionally supportive environment in the classroom, which can be created by a teacher. Emotionally healthy teacher behavior is reflected in characteristic ways of thinking, identifying, managing and expressing feelings. Emotional experience and expression are unique to each teacher and student.

\section{Need Of The Study}

Teacher's emotional intelligence determines all the achievement of the students and maintains overall performance of the school. The teacher student conflicts lead to even criminal offences. The class room environment determines the personality of a student. The good class room environment can be created by the Emotional intelligence teachers. So the researcher wants to find the emotional intelligence of the teachers.

\section{Objectives}

1. To assess the emotional intelligence of the teachers.

2. To find the relationship between subsamples and emotional intelligence of school teachers.

3. To find the predictors of emotional intelligence of school teachers.

\section{Hypothesis}

1. The emotional intelligence of the teachers is low.

2. There is no significant relationship between subsamples and emotional intelligence of school teachers.

3. There is no significant predictor of emotional intelligence of school teachers. 


\section{Materials And Methods}

A Normative Survey Method has been used in the present investigation. By using Random Sampling Technique 150 teachers are selected from Cuddalore District in Tamil Nadu and used as subjects of this study. Emotional Intelligence scale constructed and validated by Hyde, Dhar, \& Pethe, (2001) was used to collect the data. In the present study the word emotional intelligence means the scores gained by sample subject on Emotional Intelligence Scale. The Emotional Intelligence scale comprises of ten factors viz; Self-awareness, empathy, self-motivation, emotional stability, managing relations, integrity, self-development, value orientation, commitment, and altruistic behavior. As per the manual, the tool interpretation has been made i.e. maximum score indicates high emotional intelligence and minimum score indicates low emotional intelligence. The reliability and validity of the scale is $\mathbf{0 . 8 8}$ and $\mathbf{0 . 9 4}$ respectively.

\section{Analysis And Interpretation}

The researcher used descriptive deferential and regression analysis to prove or disprove the hypothesis through IBM SPSS19.

\begin{tabular}{|c|c|c|c|}
\hline \multicolumn{4}{|c|}{ Table-1 Percentage analysis of Emotional intelligence score of the total sample } \\
\hline S.No & Emotional intelligence & Score & Percentage \\
\hline 1 & Very Low & $0-34$ & 0 \\
\hline 2 & Low & $35-68$ & 0 \\
\hline 3 & Moderate & $69-102$ & 0 \\
\hline 4 & High & $103-136$ & 3 \\
\hline 5 & Very high & $137-170$ & 97 \\
\hline
\end{tabular}

The above table shows that $97 \%$ of teacher's emotional intelligence is very high and $3 \%$ of teacher's emotional intelligence is high.

\begin{tabular}{|l|l|l|l|}
\hline \multicolumn{4}{|c|}{ Table 2. Mean and standard deviation of Emotional intelligence of Total sample. } \\
\hline Variable & Mean & N & SD \\
\hline Emotional intelligence & $\mathbf{1 5 0 . 3 9}$ & $\mathbf{1 5 0}$ & $\mathbf{7 . 2 1}$ \\
\hline
\end{tabular}

The above table shows the mean score and standard deviation of Emotional intelligence of teachers, which are found to be 150.39 and 7.21 respectively. It is concluded that the teacher's Emotional intelligence is very high.

\begin{tabular}{|c|c|c|c|c|c|c|}
\hline \multicolumn{7}{|c|}{ Table.3. Deferential Analysis Of Emotional Intelligence Of High School Teachers } \\
\hline S.No: & \multicolumn{2}{|c|}{ Variables } & Mean & SD & $\mathbf{T} / \mathbf{F}$ & result \\
\hline \multirow[t]{2}{*}{1} & \multirow[t]{2}{*}{ Gender } & Female & 147.63 & 8.73 & \multirow[t]{2}{*}{-5.06} & \multirow[t]{2}{*}{$\mathbf{S}$} \\
\hline & & Male & 153.15 & 3.60 & & \\
\hline \multirow[t]{3}{*}{2} & \multirow[t]{3}{*}{ Age } & $30-39$ & 147.19 & 8.39 & \multirow[t]{3}{*}{3.85} & \multirow[t]{3}{*}{$\mathbf{S}$} \\
\hline & & $40-49$ & 150.56 & 7.61 & & \\
\hline & & $50-59$ & 152.10 & 4.51 & & \\
\hline \multirow[t]{2}{*}{3} & \multirow[t]{2}{*}{ Locality } & Urban & 151.13 & 5.59 & \multirow[t]{2}{*}{1.75} & \multirow[t]{2}{*}{$\mathbf{S}$} \\
\hline & & Rural & 147.52 & 11.15 & & \\
\hline \multirow[t]{2}{*}{4} & \multirow[t]{2}{*}{ Type of school } & Aided & 149.64 & 6.80 & \multirow[t]{2}{*}{-.97} & \multirow[t]{2}{*}{ NS } \\
\hline & & Government & 150.82 & 7.44 & & \\
\hline \multirow[t]{2}{*}{5} & \multirow[t]{2}{*}{ Qualification } & UG & 149.95 & 8.89 & \multirow[t]{2}{*}{-.76} & \multirow[t]{2}{*}{$\mathbf{S}$} \\
\hline & & PG & 150.84 & 4.94 & & \\
\hline \multirow[t]{4}{*}{6} & \multirow[t]{4}{*}{ Major Subject } & Language & 151.27 & 5.78 & \multirow[t]{4}{*}{2.15} & \multirow[t]{4}{*}{$\mathbf{S}$} \\
\hline & & Maths & 145.65 & 12.06 & & \\
\hline & & Science & 150.86 & 6.68 & & \\
\hline & & Social Science & 151.19 & 4.84 & & \\
\hline \multirow[t]{3}{*}{7} & \multirow[t]{3}{*}{ Classes handled } & $6-8$ & 147.96 & 9.30 & \multirow[t]{3}{*}{2.02} & NS \\
\hline & & $9-10$ & 151.08 & 6.24 & & \\
\hline & & $11-12$ & 150.25 & 8.01 & & \\
\hline 8 & Designation & BT & 150.42 & 7.02 & -.14 & NS \\
\hline & & PGT & 150.18 & 8.40 & & \\
\hline 9 & Monthly Income & $20001-40000$ & 150.03 & 7.49 & .62 & NS \\
\hline & & $40001-60000$ & 150.76 & 6.94 & & \\
\hline 10 & No of Dependent & $1-2$ & 149.59 & 7.77 & 1.45 & NS \\
\hline & & $3-4$ & 150.70 & 6.79 & & \\
\hline & & 5 and above & 149.05 & 9.25 & & \\
\hline 11 & No of Children & 1 & 148.12 & 9.75 & 5.74 & $\mathbf{S}$ \\
\hline & & 2 & 151.47 & 5.72 & & \\
\hline 12 & Spouse & Employed & 149.71 & 7.84 & -1.40 & NS \\
\hline & & Unemployed & 151.38 & 6.11 & & \\
\hline 13 & Spouse Salary & $0-20000$ & 151.34 & 7.42 & 19.02 & $\mathbf{S}$ \\
\hline & & $20001-40000$ & 151.18 & 4.37 & & \\
\hline & & $40001-60000$ & 138.20 & 11.10 & & \\
\hline
\end{tabular}


An independent sample $t$ test showed that the difference in score between male and female teacher is statistically significant. The difference in score between different age group of teachers is statistically significant. The difference in score between rural and urban teachers is statistically significant. The difference in score between government and Aided school teachers is statistically not significant. The difference in score between UG and PG qualified teachers is statistically significant. The difference in score between teacher with different major subject is statistically significant. The difference in score between teachers handling different class is statistically not significant. The difference in score between teachers with different designation is statistically not significant. The difference in score between teachers with different monthly income is statistically not significant. The difference in score between teachers with different no of dependents is statistically not significant. The difference in score between teachers with different no of children is statistically significant. The difference in score between teachers with employed and unemployed teacher is statistically not significant. The difference in score between teachers with different spouse salary is statistically significant.

\begin{tabular}{|l|l|l|l|l|l|l|}
\hline \multicolumn{6}{|c|}{ Table.4.: Stepwise Regression Between Emotional Intelligence And Other Variables } \\
\hline Model & B & Std. Error & Beta & Pearson $\mathbf{~ r ~}$ & Sr $^{2}$ & $\begin{array}{l}\text { Structure } \\
\text { Coefficient }\end{array}$ \\
\hline Constant) & 142.11 & 1.73 & & & & \\
\hline Gender & 5.52 & 1.09 & .384 & .384 & $\mathbf{0 . 1 5}$ & 1 \\
\hline $\begin{array}{l}\text { Note. The dependent variable emotional intelligence. } \mathrm{R}^{2}=0.148 \text { Adjusted } \mathrm{R}^{2}=0.142 \\
\mathrm{sr}^{2} \text { is squared semi-partial correlation. } \\
* p<.05\end{array}$ \\
\hline
\end{tabular}

The prediction model contained one of the Thirteen predictors and was reached in one steps with 12 variables removed. The model was statistically significant, $F(1,148)=25.61, p<.001$, and accounted for approximately $15 \%$ of the variance of Emotional intelligence $\left(\mathrm{R}^{2}=0.148\right.$ Adjusted $\left.\mathrm{R}^{2}=0.14\right)$. Emotional intelligence is primarily predicted by gender. The raw and standardized regression coefficient of predictors together with their correlation with Emotional intelligence, their squared semi-partial correlations, and their structure coefficients are shown in table-4. The gender received the strongest weight in this model. With the sizeable correlations between the predictors, the unique variance explained by each of the variables indexed by the squared semi-partial correlation was relatively low: The Gender uniquely accounted for approximately $15 \%$ of the Emotional intelligence. Inspection of the structure coefficient suggests that The Gender were relatively strong indicators of Emotional intelligence.

\section{Conclusion}

Gender, age, locality, Qualification, Major subject, Number of children and Spouse salary showed significant relationship with emotional intelligence. Among the 13 predictors gender was found as a strong indicator of emotional intelligence of teachers and accounted for approximately $15 \%$ of the variance of emotional intelligence. Male in 50-59 age group, living in urban, with PG qualification, teaching language or social sciences, having 3-4 dependents, with low spouse income are emotionally more intelligent than others. These teachers can be used as resource persons to teach others to handle their emotions positively.

\section{References}

[1]. Abraham,Y.(2014).Emotional Intelligence, Self-Esteem and Academic Achievement of Professional Course Students, Edutracks, 14(2).

[2]. Anita Menon,\&Shweta.(2014).Effect of Emotional Intelligence, Social Intelligence and Spiritual Intelligence on Academic Achievement of College Students, Journal of Education \& Psychological Research, 4(1).

[3]. Binulal,K.R.(2015).Emotional Intelligence of Student Teacher in Relation to their Social Skills and Teaching Competency, Edutracks, 14(6).

[4]. Jasmine Sheila Burney.\&Amalraj.A.(2013).Emotional Intelligence of Teachers Working in Non-Matriculation Schools, Light House, Journal of Education Reflection, 1(1).

[5]. Joshith, V.P. (2012).Emotional Intelligence as a tool for Innovative Teaching, i-manager's Journal on Educational Psychology, $5(4)$.

[6]. Lokanadha Reddy, G. \& Vijaya Anuradha, R.(2013).Emotional Intelligence, Occupational Stress And Job Performance of Higher Secondary Teachers: A Correlation Study, Edutracks, 12(6)

[7]. Mahmood Alam.(2011).Career Maturity among Adolescents as a Function of Emotional Intelligence and Self-Efficacy, International Journal of Educational Research, Development and Extention, 2.

[8]. Marlow Ediger.(2012).Teaching Mathematics and Emotional Intelligence, Experience in Education, 1.

[9]. Neha Sharma.(2014). Development of Emotional Intelligence Scale for the Secondary School Students, Journal of Community Guidance \& Research, 31(2).

[10]. Nicole R Skaar.\&John E Williams.(2012).Emotional Intelligence as a Predictor of Adolescent risk Behavior Participation and Perception, i-manager's Journal on Educational Psychology, 5(4).

[11]. Parthana.(2012).Developing Emotional and Spiritual Intelligence in Students for Resolution of Conflict, Journal of Community Guidance \& Research, 29(1).

[12]. Poornima,R.\&Lokanadha Reddy,G.(2011).Emotional Intelligence and Occupational Stress of Special Education Teachers Working In The Schools For Hearing Impaired Children, Edutracks, 10(12). 
[13]. Poornima, R. \& Lokanadha Reddy, G.(2012).Emotional Intelligence As A Tool To Enhance Quality In Teacher Education Programs, Edutracks, 11(12)

[14]. Pratik Upadhyaya.(2012).Emotional Intelligence of Normal and Handicapped Student teachers A comparative Study, Experience in Education, 1.

[15]. Rajkumari J Punjabi.(2015).Emotional Intelligence Among B.Ed. Teacher Educators, Journal Of Education \& Psychological Research, 5(2).

[16]. Ram, M. B. \& Anwar, G.(2012).Relationship Between Emotional Intelligence And Personality Adjustment Among TeacherTrainees, Edutracks, 11(12).

[17]. Shalini Yadav. \& Nisha Sharma.(2013).A Study Emotional Intelligence and Self Concept of B.Ed. Students, Journal of Educational \& Psychological Research, 3(2).

[18]. Shalini Yadav.(2014).Emotional Intelligence and Self Concept of Govt. and Private Schools Students. A Comparative Study, Journal of Education \& Psychological Research, 4(1).

[19]. Sheeba Beracah, K. L.(2015).A Study Emotional Intelligence of Prospective Teachers of Southern Districts of TamilNadu, journal of humanities and social science, 7(1).

[20]. Sheeba Beracah, K. L.(2015).A Study on Emotional Intelligence of Prospective Teachers of Southern District of Tamilnadu, Jounal of Humanities and Social Sciences, 7(1).

[21]. Shilpa Agarwal.(2013).Creativity of Senior Secondary School Students in Relation to their Emotional Intelligence, Journal Of Education \& Psychological Research, 3(2).

[22]. Sreenivasulu, B. \&Kumar Reddy, B.S.(2012).Teachers Effectiveness In Relation To Mental Health, Stress And Emotional Intelligence, Edutracks, 11(11).

[23]. Srivastava,R.K.\&Anil Prasad Nautiyal.(2012).Role Of Emotional Intelligence In Achieving Life Satisfaction, Edutracks, 12(2).

[24]. Suresh Aggarwal, \&Vidhi Bhalla.(2014).A Study Of Emotional Intelligence Of Adolescents In Relation To Creativity, Journal of Education \& Psychological Research, 4(1). 